\title{
Escravos: escrita, leitura e liberdade
}

\section{Slaves: writing, reading and freedom}

https://doi.org/10.34112/2317-0972a2017V35n71p115-136

Atilio Bergamini ${ }^{1}$

RESUMO: Centenas de anúncios publicados em jornais no Brasil do século XIX apresentam pessoas escravizadas que sabiam ler e escrever. Nosso intuito é identificar elementos recorrentes nesses anúncios e delinear perfis e trajetórias de escravos que sabiam ler e escrever. PALAVRAS-ChAVE: Escravidão; cultura letrada; escravos letrados.

ABSTRACT: Hundreds of advertisements published in newspapers in nineteenth-century in Brazil present enslaved people who could read and write. Our intention is to identify recurring elements in these ads and to outline profiles and trajectories of slaves who could read and write.

KEYWORDS: Slavery; literate culture; literate slaves.

\section{JoAQUIM, O MÚSICO}

Joaquim, também conhecido como Músico, tinha mais ou menos 24 anos em 8 de fevereiro de 1858, quando fugiu da fazenda Bomsucesso em Pirahy, no Rio de Janeiro. Escravo, ao fugir estava em ferros. Enquanto fugia, de acordo com o anúncio

1. Universidade Federal do Ceará, Fortaleza, CE, Brasil. 
publicado nos maiores jornais da Corte por seu senhor (JC, 13-2-1858, p. 4) ${ }^{2}$, um dos últimos contrabandistas de escravos do mundo e barão do café, José de Sousa Breves, "talvez apresent[asse] cicatriz de açoites e sinaes dos ferros que carregava".

Joaquim tinha um apelido apropriado: sabia tocar todos os instrumentos de sopro, e o seu forte era a clarineta, instrumento erudito e popular, no qual, talvez, tangesse sonatas e polcas. De acordo com o anúncio, além de ser bom músico, entendia do ofício de alfaiate e sabia ler e escrever. Se alguém o flagrasse andando livre por aí, devia levá-lo para outra propriedade de Breves, a fazenda do Pinheiro, na freguesia do Arrozal, onde - mas isso o anúncio não diz - Sousa Breves tinha relações no campo jurídico, por ter sido juiz de paz. A pessoa que entregasse Músico receberia 200 mil réis. Ótimo valor, pois, quando Machado de Assis ficcionalizou a prática de caçar escravos, em "Pai contra mãe" (2008a), conto publicado em 1906, colocou seu narrador e também seu protagonista surpresos com um anúncio que "subia", por volta de 1850 , a 100 mil réis.

Dissemos que Joaquim trazia cicatrizes. De açoites. É que, afirma Breves, cometeu grave crime (certamente não tão grave quanto ser contrabandista de escravos). O júri de Pirahy absolveu Músico "por falta de provas, mas que seu senhor entendeu dever corrigi-lo". Sabemos que o anúncio "talvez" mostre Joaquim com cicatrizes de açoites e sinais de ferro "que carregava" "por causa de grave crime que cometeu". Sabemos também que utilizou um "mas" para conjugar as informações de que um júri absolvera o escravo por falta de provas e de que o seu senhor o prendera em ferros. Portanto, sugere um senhor de escravos, entre os mais poderosos do País, procurando justificar atitudes.

É verdade que uma lei de 1835 disciplinava o uso de chibatadas e ferros e que - de acordo com ela - Breves teria cometido mais uma ilegalidade. É verdade que a lei não foi cumprida. Breves, então, chicoteou e pôs em ferros e esperava contar com o apoio dos leitores do jornal.

É só isso que sabemos de Joaquim, por enquanto. É um homem escravizado, vinte e poucos anos, alfaiate, sabe ler e escrever, é um bom músico. E fugiu. Livrou-se.

Haveria muita coisa que discutir a partir dessa figura. Ela condensa inúmeros processos históricos: o colapso mundial do tráfico de escravos e da segunda escravidão; a perda de legitimidade da propriedade escravista; a formação do direito

2. Utilizamos a seguinte convenção: JC, para Jornal do Commércio, seguido da data de publicação e da página. Portanto, em JC, 13-2-1858, p. 4, lê-se Jornal do Commércio, 13 de fevereiro de 1858, página 4. 
moderno no Brasil. Porém, chama a atenção um fato que, por assim dizer, não deveria estar ali: Joaquim sabe ler e escrever. Será uma exceção? Ou haveria outros escravos que, como ele, sabiam ler e escrever? Como aprendiam essa técnica tão importante? Como a utilizavam? Que sentidos davam à prática da leitura e da escrita?

\section{RAYMUNDO, O PROFESSOR}

Para discutir as perguntas acima, podemos partir de anúncios parecidos com aquele no qual conhecemos um pouco sobre Joaquim, isto é, anúncios de pessoas escravizadas em fuga, publicados no Jornal do Commércio (daqui por diante JC). Entre esses anúncios veiculados de 1830 a 1888 , encontramos ${ }^{3} 239$ em que apareciam pessoas escravizadas retratadas pelos senhores como pessoas que "sabiam ler e escrever". Descartamos os anúncios repetidos; portanto, aqueles 239 se referem a diferentes pessoas escravizadas. Somados os anúncios de pessoas escravizadas em fuga, que sabiam ler e escrever, com aqueles de pessoas escravizadas à venda, para aluguel ou em situações complexas de tutela e concessão, também anunciadas como habilitadas a ler e escrever, chegamos, apenas no que se refere ao JC, a cerca de 300 anúncios, 300 pessoas.

Escolhemos o JC porque foi um dos mais longevos periódicos do século XIX. Publicado durante todo o período que nos interessa, já que iniciou suas atividades em 1827, circula ininterruptamente até hoje. Por ser o único caso de jornal da Corte com essas características, pesquisar seus anúncios permitiu que obtivéssemos uma série de mais de seis décadas. Para os efeitos deste texto consideraremos, contudo, os anos de 1830 a 1888. O Diário do Rio de Janeiro tem igualmente uma série de décadas de publicação, mas interrompeu sua circulação por alguns anos no final da década de 1850. Como

3. Utilizo, ao longo deste texto, a primeira pessoa do plural para indicar que a pesquisa da qual este texto resulta advém de um longo trabalho coletivo que remete, talvez, a mais de uma década de encontros e diálogos. No que se refere particularmente a este artigo, cabe referir os três bolsistas de iniciação científica da Universidade Federal do Ceará, Agno Monte, Elano Lima e Rinaldo Vianna Pessoa Filho, que ajudaram a coletar os dados e organizar hipóteses. $O$ texto também deve muito à leitura seguida de sugestões que Suene Honorato (Universidade Federal do Ceará) fez de uma versão preliminar, e a contribuições de Janaína Tatim (Unicamp) e de Márcia Abreu (Unicamp). Ao longo de 2014, contei com a interlocução de participantes do projeto de cooperação internacional “Circulação Transatlântica dos Impressos”, na Unicamp, principalmente no que se refere a questões concernentes ao tratamento metodológico de anúncios de jornal do século XIX. Tenho, é evidente, total responsabilidade pelas escolhas feitas aqui. 
uma parte dos anúncios publicados nesse periódico repete os anúncios publicados no JC, este último pareceu ser mais representativo para o início da pesquisa.

A análise dos cerca de 300 anúncios publicados no JC entre 1830 e 1888 evidenciou crescente presença de pessoas escravizadas "naturais" ou "vindas" do "Norte", o que abarca, aproximadamente, o que hoje chamamos Norte e Nordeste. As províncias da Bahia, do Ceará e de Pernambuco foram as três mais referidas, tendo o Pará e o Piauí presença menor. Somente parte dos anúncios informa o local de origem das pessoas escravizadas, mas, considerando 48 anúncios (entre 239 exclusivamente de pessoas escravizadas em fuga) que traziam pessoas com origem no "Norte", coube-nos perguntar: certo número delas aprendia a ler e escrever nas províncias? Em quais províncias?

Pesquisamos de maneira panorâmica jornais das províncias e encontramos pessoas escravizadas letradas em diversas delas. Nosso interesse, todavia, tinha foco especialmente nas três províncias de origem de pessoas escravizadas na Corte mais citadas nos anúncios do JC: Bahia, Ceará e Pernambuco, isto é, o "Norte". Os jornais da Bahia e do Ceará trazem informações menos numerosas a respeito de nosso tema, não chegando a uma dezena de anúncios.

$\mathrm{Ou}$ seja, a Corte traria mais possibilidades para escravos aprenderem a ler e escrever. Todavia, no Diário de Pernambuco (de agora em diante DP), encontramos, entre 1825 e 1888 , aproximadamente cem anúncios que apresentavam pessoas escravizadas que sabiam ler e escrever. Com isso, pudemos concluir que havia pelo menos dois polos de alfabetização de escravos no Brasil: o Rio de Janeiro e Pernambuco ou, mais provavelmente, a Corte e Recife.

Em resumo, obtivemos, no JC, 239 anúncios com presença de escravos em fuga que sabiam ler e escrever, mais aproximadamente 65 de escravos para aluguel, à venda ou ainda em outras condições. Também obtivemos, no DP, 87 anúncios de fuga entre 1830 e 1888 e 21 anúncios de escravos em condições diversas. Embora as hipóteses que formularemos a seguir digam respeito ao fichamento, à catalogação e à análise comparativa de todos esses anúncios, trabalharemos apenas com o conjunto dos 239 anúncios de pessoas escravizadas fugidas e que sabiam ler e escrever, publicados no JC entre 1830 e 1888, a partir do qual pudemos refinar mais nossas análises e discussões. Não temos conviçção de que encontramos todos os anúncios com essas características, mas podemos afirmar que lemos e analisamos boa parte deles, no JC e no DP. Não temos qualquer pretensão de esgotar a fonte. Nossa ideia 
é, pelo contrário, apresentá-la e defender o interesse que ela pode ter no campo das discussões sobre cultura letrada no século XIX.

Antes de avançar, pode ser útil expor hipóteses construídas a partir da análise de evidências colhidas em outros jornais, além do JC e do DP. Seria uma pena não relatarmos ao menos aquela que consideramos a mais relevante: a de que a leitura talvez fosse mais disseminada do que a escrita no século XIX brasileiro. Uma das evidências que poderia se somar a outras para atestar essa possibilidade está presente em um anúncio publicado no jornal O Cearense em 30/o1/1874, no qual conhecemos Raymundo, pessoa escravizada que "sabe ler e escrever, é muito prosista e com predileção a ensinar a ler onde chega". Raymundo tem predileção por ensinar a "ler" e não a "ler e escrever". Não temos elementos para maiores discussões, mas é certo que Raymundo ensinava a ler onde chegava. Era um professor fugindo da escravidão.

\section{Elites letradas e povo iletrado?}

É um lugar comum sobre o século XIX brasileiro afirmar-se que somente as elites liam, ainda que pouco e mal. O povo, os trabalhadores, os pobres, os escravos não liam, não escreviam, não pensavam, eram, na expressão utilizada por Perdigão Malheiro, seguindo a tradição aristotélica, "instrumento vivo de trabalho"; ou ainda, na opinião de Caio Prado Jr. (2000, p. 280), animalidade, irracionalidade e barbárie feitas carne corruptora da cultura mais alta e dominante. Nesse caso, Joaquim e Raymundo seriam exceções. Pode ser. Mas é preciso, antes de concluir, fazer algumas reflexões.

Se aceitarmos que as elites econômicas (proprietários de terras, de escravos e de outros bens de produção), as elites políticas e as elites culturais (jornalistas, escritores, advogados, professores) formavam um conjunto restrito da população - embora não haja estudos medindo qual seria o tamanho dessa população - e se, ao mesmo tempo, aceitarmos a especulação, presente nos jornais dos anos 1860 e 1870 , logo, anterior ao censo de 1872 , de que havia $1 / 8$ ou talvez $1 / 10$ da população que sabia ler e escrever, então é preciso aceitar que boa parte dos leitores não pertencia àquelas elites - afinal, elas estavam bem longe de ser $10 \%$ da população. De acordo com estimativas do IBGE, havia aproximadamente 5,3 milhões de habitantes no 
Brasil em 1830, 8 milhões em 1850 e 9,8 milhões em $1870^{4}$. Se pudermos levar adiante esse exercício de produção de questões, podemos dizer que em 1870 algo próximo de 900 mil pessoas sabia ler e escrever no Brasil. Seria então possível trabalhar com a hipótese de que, no Brasil do século XIX, havia poucas pessoas alfabetizadas, mas, entre elas, poucas pertenciam à elite econômica e política?

Nossa pesquisa trabalha nas fronteiras da hipótese que afirma que somente a elite lia e escrevia, ou seja, estamos mais inclinados a pensar justamente o contrário, isto é, que a maior parte dos alfabetizados no século XIX brasileiro pertencia aos setores populares. Essa hipótese - sustentada atualmente por um denso campo de estudos $^{5}$ - pode ser explorada e, até certo ponto, sustentada a partir de uma variedade grande de indícios, entre os quais estão os anúncios em que figuram pessoas escravizadas que sabiam ler e escrever. Além desses indícios, já por si numerosos, a hipótese é corroborada pela quantidade de anúncios em que, por exemplo, caixeiros e feitores se oferecem para trabalhar, asseverando que sabem ler, escrever e contar. Se passássemos a calcular e analisar esses anúncios, não faríamos outra coisa, pois são várias centenas e, bem provavelmente, milhares. São igualmente numerosos anúncios em que administradores, barbeiros, comerciantes, guarda-livros, negociantes, sangradores, tropeiros, entre muitas outras profissões, aparecem ligados à prática da escrita e da leitura. Outras pesquisas têm trazido diferentes indícios das práticas de leitura e escrita por setores populares do século XIX (ver adiante principalmente seções 3.1, 3.2 e 3.3).

A série de quase seis décadas de anúncios em que aparecem pessoas escravizadas que sabiam ler e escrever deixou claro que, pouco a pouco, a sociedade brasileira passou a valorizar a escrita e a leitura. Não somente os anúncios contam essa história. A famigerada Lei Saraiva, de 1881, excluía da possibilidade de votar,

4. Dados disponíveis em: <http://www.ibge.gov.br/home/estatistica/populacao/censohistorico/1550_1870. shtm> e em: <http://www.ibge.gov.br/home/estatistica/populacao/censohistorico/1872_1920.shtm>. Links acessados em: 15 ago. 2017.

5. Ao longo deste artigo, dialogamos principalmente com alguns pesquisadores que se dedicam à questão das práticas de escrita e leitura feitas por escravos. As pesquisas aqui referidas e discutidas formam apenas uma fração do campo de estudos que tem aprofundado o conhecimento disponível sobre práticas de escrita e leitura de setores populares. Pesquisas realizadas no âmbito do projeto "Circulação Transatlântica dos Impressos”, coordenado por Márcia Abreu e Jean-Yves Mollier, mapearam apropriações de obras literárias por diversos estratos das populações brasileira, francesa e inglesa do século XIX, a partir de estudos de caso e de tratamentos estatísticos. Há centros, grupos ou esforços diversos de pesquisa sobre assuntos correlatos ao menos na Universidade Federal do Pará, na Universidade Federal de Pernambuco, na Universidade Federal Fluminense e na Universidade Federal de Alagoas. 
entre outros, indivíduos que não soubessem ler e escrever. Tudo indica que a lei foi somente um aspecto da constelação de forças que ia inserindo o saber ler e escrever entre as habilidades fundamentais para formar o "cidadão brasileiro".

Profissões como a de carteiro, a partir dos anos 1850, exigiam, como é óbvio, saber ler e escrever. Outras funções, principalmente aquelas "de ofício", como alfaiataria, carpintaria, cozinha e marcenaria, pareciam ser especialmente indutoras de letramento, fosse entre homens livres, fosse entre escravos. De fato, encontramos, nos anúncios, escravos que sabiam ler e escrever e eram advogados, alfaiates, barbeiros, boleeiros e cocheiros, caldeireiros, calafates, carregadores de café, carpinteiros, chapeleiros, charuteiros, copeiros, cozinheiros, empalhadores, ferradores, ferreiros, lustradores, maquinistas, marceneiros, mucamas, músicos, oficiais de propiagem, ourives, pajens, padeiros, pedreiros, pintores, sapateiros, tipógrafos.

\subsection{OFICINAS}

Embora o "ofício" tenha sido proibido já pela Constituição de $1824^{6}$, as oficinas que ensinavam alfaiataria, cozinha, marcenaria, calafataria e carpintaria, entre outras atividades, continuaram ativas. No precioso livrinho que escreveu para a Campanha de Educação de Adultos, em 1949, outro Raymundo, o escritor Raymundo de Souza Dantas, relatou o processo de sua alfabetização, para o que colaboraram e prejudicaram, ao longo de muitos anos, a escola, a família, amigos próximos e os trabalhos em ofícios de ferreiro, marceneiro e, principalmente tipógrafo. "Primeiro aprendi os ofícios, muitos depois o alfabeto”, escreveu Dantas (1949, p. 5).

As atividades de oficinas deixaram rastros - em parte dos anúncios analisados - da existência de pessoas escravizadas “oficiais" ou "aprendizes”. Entre os 239 anúncios que estamos considerando, 31 apresentam a palavra "oficial" ou então "aprendiz" antes da profissão da pessoa escravizada (por exemplo, "oficial de alfaiate", "oficial de carpintaria”, "aprendiz de pedreiro"). Em diversos anúncios, a palavra "oficial” parece estar em elipse, portanto o conjunto de oficiais presentes nos anúncios deve ser bastante maior. De toda maneira, basta para nossos propósitos a possibilidade de que algo em torno de $13 \%$ - e provavelmente muito mais do que isso - de pessoas escravizadas que sabiam ler e escrever presentes nos anúncios tenham aprendido suas profissões em oficinas.

6. Constituição política do Império do Brazil, art. 179, inciso XXV. 
Dizíamos que o movimento - efetivado na Constituição de 1824 - de inscrever a escravidão no direito moderno e na economia moderna proibiu os ofícios (MARTINS, [2008?], p. 161 e ss.). Pretendia-se assim, a um só tempo, tirar o Brasil da "Idade Média" e colonial suposta pela relação hierárquica e desigual entre mestre-oficial-aprendiz nas oficinas, para inscrevê-lo na "Idade Moderna" da produção em grande escala.

Embora proibidas, as oficinas continuaram acontecendo. Vimos anteriormente que, em meados do século $\mathrm{XX}$, elas foram responsáveis por colaborar no processo de alfabetização de um futuro escritor. No século XIX, Jean-Baptiste Debret, que esteve no Brasil entre 1826 e 1831, pintou diversas gravuras retratando trabalhos em oficinas de sapataria e carpintaria. Além disso, é evidente a presença do "ofício" como um resto linguístico, isto é, muitos profissionais continuaram "oficiais de", o que está abundantemente documentado nos jornais. A partir de 1830, associações de auxílio mútuo continuaram disseminando a relação de aprendizagem de um ofício. Esses espaços formaram "oficiais" por décadas. Até o final do período que pesquisamos, é possível encontrar anúncios como este: "Precisa-se de oficial de carpinteiro na rua do Catete, $\mathrm{n}$ 157, loja” (JC, 1-1-1887, p. 8).

De acordo com Gladys Sabina Ribeiro (2002), nas corporações de ofício brasileiras havia "muitos escravos". Logo iniciou-se uma concorrência deles com imigrantes, principalmente portugueses (ALENCASTRO, 1988; RIBEIRO, 2002). Sociedades e irmandades surgidas nessa época procuravam apoiar seus associados nessa concorrência, ensinando-os a ler e escrever, bem como oferecendo estipêndios e ajudas quando adoeciam ou não podiam mais trabalhar.

Em Pernambuco, foi fundada, em 1841, a Sociedade dos Artistas Mecânicos e Liberais (SAMLP), formada por mestres e aprendizes de artes mecânicas, como carpinteiros, pedreiros, marceneiros e tanoeiros (LUZ, 2007, p. 314). Lembremos de que Pernambuco, não por coincidência, foi uma das províncias em que mais encontramos, em nossa fonte, pessoas escravizadas que sabiam ler e escrever. Luz (2007, p. 316 e ss.) verificou que, dos 155 sócios registrados na SAMLP, 143 eram pretos, mulatos e pardos, sendo estes últimos a maioria. Também nesse caso há correlação com os dados que encontramos, já que, como veremos, a maior parte das pessoas escravizadas que sabiam ler e escrever era classificada como pardas por seus senhores (ver, a respeito, a seção 5, adiante).

Martins ([2008?]) e Antonio Santonio Rugiu (1998) ressaltaram o caráter oral da transmissão nas corporações de ofício, mas suas pesquisas enfatizam o período 
colonial. Luz (2007, p. 318), por exemplo, verificou que os associados da SAMLP perceberam, logo após a fundação da sociedade, em 1841, a necessidade de promover o ensino da leitura e da escrita, sem o que os conhecimentos técnicos e profissionais ficariam comprometidos. O método de ensino então adotado para as aulas técnicas foi sistematizado no livro Curso normal de geometria e mecânica aplicada às artes, do Barão Dupin, disponibilizado nas livrarias de Olinda.

\subsection{TIPOGRAFIAS}

Havia algumas profissões, entre aquelas de ofício, como a de tipógrafo, em que saber ler e escrever poderia significar passar de um trabalho mais árduo para um trabalho mais reconhecido. Em $O$ capital, Marx descreve a atividade de tipógrafo em Londres em meados do século XIX como uma das mais insalubres e sujeitas à má alimentação, além de ser, depois da mecanização, uma das mais difíceis para o aprendizado das habilidades necessárias para "ascender" na profissão. "Matadouros" - era esse o apelido que os trabalhadores davam para as gráficas (MARX, 2013, p. 534, p. 555, p. 621-622, p. 753). Entre os 239 anúncios de pessoas escravizadas em fuga recolhidos do JC, encontramos dois tipógrafos que sabiam ler e escrever. Faz sentido. O escritor, jornalista e político muito atuante nos anos 1840, Justiniano José da Rocha, em artigo de 10 de dezembro de 1844 no jornal conservador O Brasil, escreveu, ao criticar uma lei que taxava tipografias: "a tipografia é uma escola, onde uma multidão de meninos vai aprender esse ofício”.

A palavra "multidão" provavelmente entra na conta de um exagero retórico, muito típico de Justiniano, mas acrescenta uma evidência para o argumento de que talvez fosse bem maior do que temos pensado a quantidade de pessoas pobres e trabalhadoras que podia aprender - em outros espaços que não fossem a escola pública - a ler e a escrever durante o século XIX. Também a palavra "escola" foi utilizada por Justiniano em sentido lato. Todavia, por isso mesmo, o trecho é interessante: fala, no final das contas, de uma multidão em escolas. "Mas" é uma multidão de trabalhadores. $\mathrm{E}$ as escolas são diferentes daquelas que, em geral, procuramos. Uma multidão que não é ninguém, aprendendo algo que muitos não consideram aprendizado, em escolas que não são escolas: trabalhadores que leem e escrevem. Nada mais estranho aos princípios de divisão que organizam narrativas sobre a formação do Brasil. 
Uma pesquisa recente a respeito da vida de Francisco de Paula Brito, um dos primeiros editores do Brasil, negro ele mesmo, revelou o papel de escravos na produção de livros: "escravos foram largamente empregados nas tipografias da Corte" (GODOI, 2016, p. 148). É preciso antecipar que nas tipografias havia funções, como as exercidas por impressores e batedores, que não exigiam saber ler e escrever. É provável que muitos escravos fossem ali explorados nessas funções. A descrição que Marx faz do trabalho nessas oficinas mostra que uma tipografia estava longe de ser uma escola (ou talvez seja bem parecida com muitas escolas no Brasil contemporâneo...). Porém, as duas pessoas escravizadas que trabalhavam em tipografias constantes nos anúncios que nos serviram de fonte sabiam ler e escrever. É o caso também de alguns dos escravos tipógrafos contratados por Paula Brito (GODOI, 2016, p. 148 e ss.).

A partir de 1831, o tráfico de escravos foi proibido (já tinha sido, em 1826, e viria a ser novamente, em 1850), o que resultou numa série de apreensões de tumbeiros. As pessoas encontradas nos porões desses navios eram "concedidas" aos cuidados de brasileiros, até que voltassem à África, embora, muitas vezes, não tenham tido essa possibilidade. Paula Brito foi concessionário de sete dessas pessoas, em geral, tratadas como escravos (GODOI, 2016, p. 157). Nessas condições brutais, alguns desses africanos aprendiam a ler e escrever em português.

Paula Brito foi o patrão do primeiro emprego de Machado de Assis. No conto "Pai contra mãe", que citamos anteriormente, o caipora protagonista chamado Candido teve entre suas primeiras profissões a de tipógrafo, trabalho considerado pesado. Depois de atuar como entalhador, viraria caçador de escravos fugidos. Em todos esses trabalhos, tipógrafo, entalhador e caçador de escravos fugidos, está explícito que a personagem, que sabe ler e escrever, lê e usa a cultura letrada. No que tange às biografias de escritores, é preciso referir Lima Barreto, cujo pai foi escravo e tipógrafo, e cuja mãe, filha de escravos, tornou-se professora (STOLZE LIMA, 2014, p. 243).

Portanto, diversas pesquisas às quais a nossa agora procura se somar verificam a hipótese de que as oficinas - apesar de "matadouros" - teriam sido um lugar de disseminação da leitura e da escrita entre pessoas escravizadas, ex-escravos e homens livres pobres. Ainda que alguns estudos demonstrem a prevalência nesses ambientes de uma transmissão oral e gestual (MARTINS, [2008?], p. 88; RUGIU, 1998, p. 34), as corporações, não raro, possuíam "autos" escritos, assim como "recomendações". De acordo com os mesmos autores, era comum a relação mestre-aprendiz ser mediada por contratos escritos e assinados. Algumas corporações passaram a trabalhar com manuais, como dissemos anteriormente (LUZ, 2007). É também possível - mas 
precisa ser comprovado por pesquisas ulteriores - que alguns manuais, como parece ser o caso do famoso $O$ Vinhola Brazileiro: novo manual prático do engenheiro, arquiteto, pedreiro, carpinteiro, marceneiro e serralheiro, escrito por César de Rainville (1880) e publicado por uma das principais editoras do Brasil da década de 1880, a Laemmert, circulassem em obras e oficinas diversas nas quais pessoas escravizadas trabalhavam.

Nos anúncios que pesquisamos, durante as décadas de 1830 e 1840 os escravos letrados se concentravam em poucas profissões (alfaiates, marceneiros, carpinteiros, cozinheiros e calafates, ou seja, justamente as profissões de “oficiais"). A partir dos anos 1850 até a abolição, escravos que sabiam ler e escrever atuavam desde carregando café até engomando roupas, em aproximadamente 29 profissões diferentes (é uma simplificação falar em "profissões", já que muitos dos anúncios apresentam escravos que fazem um pouco de tudo. Um anúncio [JC, 16-7-1881, p. 4] apresenta um escravo hábil em "todos os ofícios"). Assim mesmo, há maior quantidade de alfaiates e cozinheiros também nesse período. Na Tabela 1 é possível visualizar algumas dessas profissões e a quantidade de anúncios em que aparecem em cada década.

\begin{tabular}{|l|c|c|c|c|c|c|c|}
\hline Profissão & $\mathbf{3 0 - 3 9}$ & $\mathbf{4 0 - 4 9}$ & $\mathbf{5 0 - 5 9}$ & $\mathbf{6 0 - 6 9}$ & $\mathbf{7 0 - 7 9}$ & $\mathbf{8 0 - 8 9}$ & Total \\
\hline Alfaiates & 1 & 6 & 6 & 3 & 1 & - & 17 \\
\hline Cozinheiros & - & - & 2 & 4 & 3 & 8 & 17 \\
\hline Carpinteiros & 2 & 2 & 5 & 1 & 2 & 3 & 15 \\
\hline Pedreiros & - & 2 & 1 & 3 & 1 & - & 7 \\
\hline Sapateiros & 1 & - & 2 & 3 & - & - & 6 \\
\hline Marceneiros & - & 1 & 2 & 1 & 1 & - & 5 \\
\hline $\begin{array}{l}\text { Marceneiro e } \\
\text { carpinteiro }\end{array}$ & 2 & - & 1 & - & - & - & 3 \\
\hline
\end{tabular}

Tabela 1: Quantidade de Anúncios de Profissões por Década Fonte: Banco de Dados do Pesquisador

Não é certo e é até mesmo improvável que as tendências presentes nos anúncios "reflitam" tendências gerais da sociedade brasileira da época, mas os indícios levantados, caso sejam corroborados por outros tipos de fonte, podem apontar a variedade das profissões praticadas por pessoas escravizadas que sabiam ler e escrever - entre elas, especialmente, aquelas aprendidas em “oficinas”. Assim, é possível pensar que o aprendizado talvez se desse em oficinas, muitas vezes pouco a pouco, 
muitas vezes ficando em níveis de letramento que consideraríamos precários, mas que, para a época, eram, talvez, úteis e adequados para algumas atividades e, sobretudo, para a construção da liberdade possível naquele mundo. Falaremos a respeito a seguir. De qualquer maneira, entre as tendências apontadas, há a sugestão de uma consistente expansão, ao longo do tempo, do número de profissões em que havia trabalhadores que sabiam ler e escrever.

\subsection{Por onde Raymundo chegasse}

Em livros que tomam o anúncio de jornal como seu tema principal, caso de $O$ escravo nos anúncios de jornais brasileiros do século XIX, de Gilberto Freyre (2010), e Retrato em branco e negro, de L. M. Schwarcz (1987), ocorrem menções a pessoas escravizadas que sabiam ler e escrever mas sem que a análise recaia sobre essas práticas. Se o Brasil era marcado naquele período, como afirma outro estudo, "pela oralidade e pelo analfabetismo", então os escravos deveriam ser os mais atingidos por esse nosso mal de origem (GALVÃO et al., 2007, p. 11 e ss.).

De fato, há muitos argumentos para afirmar que não havia - ou havia poucas - pessoas escravizadas e/ou pobres que sabiam ler e escrever: em 1872, a escola elementar tinha 139.321 matrículas no Brasil (numa população de quase 10 milhões de habitantes); a tipografia chegou com a Coroa Portuguesa, em 1808; não havia faculdades ou universidades até o século XIX; praticamente não conhecemos material escrito por pessoas pobres ou trabalhadores antes do século XX; uma lei de 1854 proibiu a presença de escravos em escolas etc.

Todavia, as deduções feitas a partir desses fatos são, em geral, desamparadas de pesquisa e, muitas vezes, naturalizam a perspectiva das próprias elites sobre aprendizado e letramento. Por exemplo, o fato de menos de 140 mil estudantes estarem matriculados na escola elementar por volta de 1870 prova, sem dúvida, que, com o perdão da lapalissade, havia poucos matriculados na escola elementar, mas isso não permite concluirmos que as pessoas não aprendiam a ler e a escrever de outras maneiras. Em uma perspectiva dialética, digamos que a falta de escolas dificulta a expansão da alfabetização, mas provoca aqueles que precisam ou querem aprender a ler e escrever a fazê-lo de outras maneiras. O mesmo raciocínio serve para a lei de 1854 que proibia a presença de escravos em escolas. É certo que a lei proibiu. Mas será assim tão certo que foi efetiva? $\mathrm{E}$, sendo efetiva, será assim tão certo que pessoas escravizadas não tenham tentado outros caminhos, apesar de toda a dificuldade? 
Pode ser que a geografia do aprendizado que encontramos, ao estudar as pesquisas citadas até aqui e também ao analisar as nossas fontes, traga elementos a esse respeito. Por geografia do aprendizado queremos nos referir aos lugares nos quais, tudo indica, pessoas escravizadas cavavam um jeito de aprender a ler e escrever. Colônias de órfãos, igrejas, oficinas, casas-grandes, aonde quer que Raymundo chegasse e... até mesmo em colégios!, principalmente no Rio de Janeiro e em Pernambuco, mas também na Bahia e no Ceará, eram lugares onde pessoas escravizadas aprendiam a ler e escrever. Seguem aqui e nas próximas seções algumas evidências a esse respeito.

Adriana Maria P. da Silva (2000) pesquisou uma escola para meninos pretos e pardos, alguns deles filhos de escravos. A fonte de referência utilizada por ela foi um requerimento, em 1856, de um professor negro, Pretextato, para o chefe da instrução pública no Brasil, Eusébio de Queiróz. A conclusão de Silva, aprofundada e em parte discutida em artigo de 2007, assemelha-se com nossos resultados. No caso de Silva, a questão da cor da pele e do ensino "público" são o foco, enquanto, no nosso estudo, a posição de escravo e qualquer tipo de indício do uso (ou da representação do uso), por ele, da leitura e da escrita são o foco. Exceto por essa diferença, os dados levantados por ambos os nossos estudos indicam que, nas palavras de Silva, "o acesso às aulas públicas nas quais acontecia [o ensino de primeiras letras] não esteve restrito às elites brancas e ricas (sob qualquer ponto de vista)" (SILVA, 2007, p. 271).

Maria Cristina Cortez Wissenbach (2002) percebeu uma relação entre pessoas escravizadas que sabiam ler e sua atuação em "situações singulares do trabalho urbano" ou ainda "atividades autônomas". Não teremos espaço para desenvolver aqui uma questão importante a respeito das determinações da Igreja no processo de aprendizado da leitura e da escrita por pessoas escravizadas. Salientamos este ponto porque Wissenbach (2002, p. 110) encontrou, assim como temos encontrado, "a presença de hábitos de escrita e de leitura difundidos principalmente entre plantéis pertencentes às ordens religiosas e ao clero".

Adlene Silva Arantes (2005) narra, no final da escravidão, em diversas províncias, entre elas Pernambuco e Ceará, a criação de "colônias orfanológicas", nas quais estudaram filhos de escravos, ex-escravos e índios.

Os anúncios analisados por nós confirmam os resultados obtidos por Arantes (2005), Luz (2007), Silva (2000), Wissenbach (2002) e outros, na medida em que demonstram a necessidade de pensar a disseminação da cultura letrada no século XIX para além da "instrução pública" e muito além das "elites letradas". Encontramos nas nossas fontes, a propósito, escravos educados em "colégios" privados; e, na década de 
1880, uma discussão na Assembleia Legislativa Provincial, no Rio de Janeiro, aponta para a existência de uma escola para 40 filhos de escravos no Vale do Paraíba. Vamos ocupar alguns parágrafos para contar essa história, porque ela evidencia o costume talvez recorrente de ensinar a ler e escrever a partir de pequenas escolas privadas e porque ela nos permite reencontrar, indiretamente embora, Joaquim, o Músico.

3.4. JOAQUIM, O FILHO

Lendo o JC de março de 1877, em busca de informações sobre a "instrução pública", nos reencontramos com o sobrenome Breves. Joaquim Breves Filho (na verdade Joaquim José de Sousa Breves Filho) - que, como se vê, recebeu o mesmo nome de um dos escravos mais perseguidos e maltratados pelo seu pai, Joaquim, o Músico - era, agora, como costumava acontecer, deputado. O JC transcreve um discurso dele na tribuna da Assembleia.

Breves, "o rei do Café", é contra uma reforma que, segundo ele, estava pondo em dificuldades o "ensino livre", isto é, a possibilidade de "qualquer pessoa chamar para sua casa meia dúzia de meninos para dar-lhes essa instrução rudimental". Tudo o que segue foi retirado de JC (21-3-1877, p. 1). Aqui estão os pontos levantados por Breves Filho que interessam para a nossa discussão.

a. Breves fala de uma espécie de costume do "interior": "pobres que podem cotizar-se entre si e ensinar aos filhos ler e escrever";

b. Breves, quase chorando: "Meu pai tem em sua fazenda, desde muitos anos, uma escola onde ensina a ler, escrever e contar todas as suas crias, de sorte que a última geração de seus escravos sabe ler e escrever";

c. Breves comenta sobre dificuldade de os mais pobres arranjarem roupas para ir para as aulas;

d. Breves argumenta que, em vilas e cidades, é mais fácil aprender a ler e escrever, em razão do contato diuturno com advogados, professores, médicos e padres, enquanto nas zonas rurais somente as pequenas escolas fazem esse papel.

Em resumo, o discurso deste descendente de um dos mais violentos e, por isso mesmo, um dos mais civilizados escravistas brasileiros, comenta que mesmo famílias sem condições de dar vestimentas para os filhos tentavam, em algum momento, enviá-los para escolas. Dá conta também da existência de uma escola para escravos 
no vale do Paraíba. Sugere a existência de uma "escravaria" inteiramente letrada. Por fim, salienta que o trânsito de pessoas não alfabetizadas entre pessoas alfabetizadas poderia favorecer a alfabetização ${ }^{7}$. Não que devamos tomar as palavras de Breves, o filho, como verdadeiras. Há muito de exagero com fins retóricos e muito de demagogia em cada argumento. Porém, retórica e demagogia são, a seu modo, indícios de um assunto suficientemente importante para ser defendido na Assembleia. Mais do que descrever escravos que aprenderam a ler e escrever, o discurso de Breves representa como um proprietário de escravos gostaria de ser entendido: um sujeito que promove a civilização, inclusive ensinando a ler e escrever.

Machado de Assis, menos de uma semana depois da abolição, publicou uma crônica na Gazeta de Notícias. A crônica, escrita do ponto de vista de Breves, ou melhor, de algum senhor de escravos, encerra da seguinte maneira:

O meu plano está feito: quero ser deputado, e, na circular que mandarei aos meus eleitores, direi que, antes, muito antes da abolição legal, já eu, em casa, na modéstia da família, libertava um escravo, ato que comoveu a toda a gente que dele teve notícia; que esse escravo, tendo aprendido a ler, escrever e contar (simples suposição), é então professor de filosofia no Rio das Cobras; que os homens puros, grandes e verdadeiramente políticos não são os que obedecem à lei, mas os que se antecipam a ela, dizendo ao escravo: és livre, antes que o digam os poderes públicos, sempre retardatários, trôpegos e incapazes de restaurar a justiça na terra, para satisfação do céu. (MACHADO DE ASSIS, 2008, p. 812).

É de se ver que a história do outro Joaquim, o Músico, se entrelaça com outras histórias de pessoas escravizadas que sabiam ler e escrever e aprendiam a fazê-lo de diversas maneiras. Porém, precisamos, para contá-la, lidar crítica e dialeticamente com a perspectiva dos senhores, a partir da qual, no fim das contas, estamos colhendo nossos indícios.

\section{JuAn Francisco Manzano}

Em A autobiografia do poeta escravo, Juan Francisco Manzano (2015), escravizado em Cuba, apresenta cenas que podem ajudar a pensar a relação entre pessoas

7. Na autobiografia que escreveu, Luiz Gama comenta que aprendeu a ler e escrever com a ajuda de um estudante de Direito. 
escravizadas e a cultura letrada. Manzano escreveu por volta de 1835 . Ele se mostra um atento observador dos movimentos de pessoas que escrevem e desenham ao seu redor. Assim, logo se transforma em exímio retratista, além de ser muito bom em fazer versos de improviso (no que se assemelha a Balthazar, pessoa escravizada que encontramos em sucessivos anúncios [JC, 23-9-1878, p. 5, replicado pelo menos oito vezes até janeiro de 1879 ] como um sujeito "dado a dizer versos").

Embora as atividades observadas por Manzano não se relacionem diretamente com a escrita, indiretamente elas indicam um aprendizado precoce e autodidata da coordenação motora fina exigida pelo uso de canetas de penas, grafites e pincéis. Além disso, em alguns momentos de sua narrativa, Manzano observa sua "dona" escrevendo. Essas duas experiências eram comuns também entre pessoas escravizadas no Brasil. Alguns ofícios exigiam a prática de desenho; gravuras de Rugendas e de Debret retratam sinhás ou sinhazinhas estudando, rodeadas por escravos.

Em peças do teatro realista brasileiro, que procurava "imitar" os costumes locais, encontramos duas passagens que dramatizam o que estamos discutindo. $\mathrm{O}$ drama História de uma moça rica, de Pinheiro Guimarães (1861), traz uma cena em que uma mucama discute com um escravo. Ele diz que a senhora dela foi muito boa, ao ensiná-la a ler e escrever, e que até emprestou romances para que ela lesse. Meses antes, Machado de Assis publicara um pequeno ato cômico, Hoje avental, amanhã luva, no qual um escravo boleeiro lê o JC e é repreendido pelo senhor. O escravo retruca: "Eu estava embebido com a interessante leitura do Jornal do Comércio: ei-lo. Muito mudadas estão estas coisas por aqui! Não faz uma idéia! E a política? Esperam-se coisas terríveis do parlamento". O senhor xinga o escravo, que responde: "Sim, senhor; mas admira-me que V. S. não preste atenção ao estado das coisas". O senhor volta a xingá-lo: "Pedaço de asno! Sempre a ler jornais" (2008b, p. 863-874).

Wissenbach (2002) revela que a posse de papel e caneta de pena assumiu grande importância entre escravos e libertos, pois a "carta" de alforria transformava a liberdade desejada na liberdade obtida (ou quase), constituindo-se, de fato, no único documento capaz de distinguir os forros dos escravos. Entre os anúncios pesquisados, encontramos variações da seguinte expressão: "Julga-se que vai se inculcar forro" (JC, 3-3-1836, p. 3-4). A relação lógica entre saber ler e escrever e "se inculcar forro" aparece explicitamente em pelo menos 35 dos anúncios em tela, como nestes casos:

- "Inculca-se forro o que é um tanto mais fácil quanto o mesmo sabe ler, escrever e contar, além de ser perito alfaiate” (JC, 11-3-45, p. 4); 
- "Julga-se que ele sabe ler e escrever e por isso intitula-se forro" (JC, 9-1-1851, p. 3, republicado em pelo menos outras seis ocasiões). - "Sabe ler e escrever e deve mostrar papéis falsos em como é forro" (JC, 16-1-1861, p. 3). - "Desconfiase que anda com documento falso, pois sabe ler e escrever alguma coisa" (JC, 13-7-1884, p. 7).

Do ponto de vista dos anunciantes, essas pessoas escravizadas podiam representar a si mesmas como livres, "pois" sabiam ler e escrever. Ao forjar documentos, os libertos por si próprios podiam mudar nome e sobrenome, o que também está fartamente apresentado nos anúncios. Assim, encontram seus limites as maneiras como o deputado Breves e o futuro deputado personagem da crônica de Machado de Assis representam a escrita e a leitura de escravos.

\subsection{Dizem Que...}

Se menos - ou por volta de $-10 \%$ da população sabia ler e escrever durante os anos 1850, 60 e 70, então essa característica era excelente para que os senhores pudessem identificar pessoas escravizadas fugidas. Talvez seja essa a razão para que alguns anúncios tragam as seguintes expressões:

- "Dizem que sabe ler e escrever" (JC, 18-12-1832, p. 4);

- "Adverte-se que sabe ler e escrever" (Jornal deteriorado, sem data clara);

- "Julga-se que ele sabe ler e escrever e por isso intitula-se forro" (JC, 9-1-1851, p. $3-4)$;

- "Conquanto negue sabe ler e escrever" (JC, 22-6-1852, p. 4);

- "Consta que sabe ler e escrever" (JC, 8-1-1867, p. 3);

- "Supõe-se que sabe ler e escrever" (JC, 12-6-1867, p. 3);

- "Julga-se que sabe ler e escrever" (JC, 10-8-1868, p. 3);

- "Sabe ler e escrever mas não o diz" (JC, 4-10-1874, p. 7);

- "Desconfia-se que sabe ler e escrever" (JC, 30-6-1881, p. 6).

A desconfiança desses senhores evidencia que, para parte dos escravos, não era prudente dar a ver seus conhecimentos de escrita e leitura. Esse perfil, nos anúncios, é um mais presente do que o perfil de pessoas escravizadas que foram educadas com "incentivo" do senhor, como aquelas que sabem ler e escrever em francês e português 
(JC, 27-9-1855, p. 4). Ou seja, alguns senhores encaminhavam a alfabetização de alguns escravos, enquanto outros, aparentemente a grande maioria, dificultavam esse processo. É, portanto, como uma habilidade ao mesmo tempo incentivada por alguns senhores e dificultada por muitos deles, que os anúncios nos convidam a pensar a escrita e a leitura desde a perspectiva da relação entre senhores e escravos.

Evidencia-se - nos momentos em que os senhores tanto apontam que seus escravos se inculcam forros, quanto desconfiam que seus escravos sabem ler e escrever, mas não o dizem - que, do ponto de vista dos senhores, a escrita está ligada com a possibilidade de o escravo representar sua própria liberdade em documentos, papéis, passaportes e projetos de vida. Um desses senhores chegou a se expressar assim a respeito de seu escravo: "Consta que anda munido de um escripto" (JC, 13-7-1855, p. 4).

Seria preciso discutir, a partir da interpretação que fazemos da fonte de nossa pesquisa, as maneiras como uma tradição de pensamento sobre o Brasil, de Joaquim Nabuco até Caio Prado Jr. e deste até Fernando Henrique Cardoso, naturalizou a ideia de que o escravo não tinha como representar a si mesmo, por isso precisava "ser representado". Deixaremos isso para outra oportunidade, pois o escopo do presente texto é apresentar e discutir os anúncios e suas regularidades.

\section{Pardos e soldados}

Os anúncios indicam uma curiosa tendência na perspectiva senhorial a respeito da cor da pele (ou deveríamos dizer do status e da posição social?) de seus escravos fugidos. A classificação "pardo" e suas variantes "pardo claro", "pardo escuro", "pardo baio", "pardo acabouclado", "pardinho", é a mais recorrente, aparecendo em 74 ( 75 , caso computemos a referência a um escravo descrito pelo seu senhor como "claro") dos 239 anúncios analisados; já a classificação "preto" e suas variantes "preto retinto", "preto carapina", "preto mina" apareceram 20 vezes e, se somarmos as vezes em que a palavra "preto" está em elipse, como em "retinto", "fula" e "carapina", chegaremos a 36 ocorrências.

Entre os anúncios que recolhemos pode haver uma correlação entre o fato de senhores classificarem escravos como pardos e o fato de essas pessoas escravizadas saberem ler e escrever. Ou seja, para os senhores, se leitor, então tende a pardo. A correlação que estamos propondo exige cuidadosas ponderações, que já não cabem agora, com exceção da seguinte: Luiz Felipe de Alencastro (2000, p. 345-355) narra a "invenção do mulato" no Brasil a partir do processo de longa duração no qual 
africanos escravizados e, em seguida, imigrantes europeus abasteceram a mão de obra nacional, até que, por volta de 1930, passou a ser necessário, por assim dizer, reproduzir mão de obra internamente. Com isso, em uma perspectiva de longa duração teria ocorrido um "favorecimento dos mulatos" (p. 346).

Muitos processos, portanto, determinam a utilização do termo "pardo" nos anúncios (a palavra "mulato" foi utilizada somente uma vez em JC (2-7-1830, p. 4): "mulato muito escuro"). A "miscigenação": alguns pardos talvez fossem filhos de senhores brancos, o que, às vezes, poderia favorecer o acesso a bens, serviços e posições. A condição de liberdade instável de qualquer pessoa escravizada em fuga, que poderia ser minorada pela cor "branca": há anúncios em que o senhor descreve a pessoa escravizada como "pardo, contudo tem a cor muito clara e pode passar por branco", "pardo claro bem alvo" (JC, 23-9-1853, p. 3), "bastante claro" (JC, 6-2-1864, p. 3), "pardo claro, quase branco" (JC, 13-5-1874, p. 5, este anúncio foi replicado pelo menos outras seis vezes). Essas duas questões levam a outra: a possibilidade dialética de que, ao representar a si mesmo como livre, a pessoa escravizada precisava fazê-lo a partir de uma prática tida como "branca”, num complexo processo de afirmar-se e sofrer o empuxo da aculturação.

\section{CONCLUSÃo COM PERGUNTAS}

A maior parte das pessoas escravizadas que sabia ler e escrever, de acordo com os anúncios (e é preciso salientar uma vez mais que isso não significa a "realidade”), estava na Corte ou tinha vindo da Bahia, do Ceará ou de Pernambuco; era, do ponto de vista dos senhores, parda; e tinha uma profissão de ofício. Os espaços em que aprendiam a ler e escrever eram os mais variados: oficinas, igrejas, colônias orfanológicas, colégios, casas-grandes e, por suposto, onde quer que Raymundo chegasse. Essas pessoas muitas vezes utilizavam a escrita e a leitura para "se inculcar forras", representando, inclusive em termos "legais", a própria liberdade. Esta é a figura da pessoa escravizada que sabe ler e escrever, tal como os anúncios analisados permitem vislumbrar'.

8. Não foi possível ter certeza sobre a data de publicação, pois o jornal está muito deteriorado e ainda não era publicado diariamente. Neste caso, optamos por referir com o link disponível em: <http://memoria.bn.br/ DocReader/364568_02/4518>.

9. Uma característica, entre outras tantas, cuja análise terá que ficar para outra oportunidade, é a presença crescente, a partir do período da Guerra do Paraguai, de pessoas escravizadas que decidiram assentar praça. 
Ao defender a hipótese de que havia entre as pessoas escravizadas um número maior do que o que estamos acostumados a admitir de pessoas que sabiam ler e escrever, esperamos que não nos leiam como insinuadores de um escravismo bom, cheio de oportunidades etc. Tratou-se de um genocídio (NASCIMENTO, 2016). É preciso começar daí.

Isso posto, setores da população escreviam e liam, escreveram e leram, sem que seus tipos de leitura e escrita apareçam nas teorizações, sobretudo aquelas que circulam no campo de estudos no qual nos incluímos, isto é, o da teoria da literatura. Ao invés de manter dualidades classificatórias - como intelectuais versus massa ou elites letradas versus povo iletrado ou, ainda, elite pensante versus trabalhadores braçais em que, no primeiro momento, temos literatura, arte, civilização, sofisticação, ironia, refinamento, inteligência e, no segundo momento, analfabetismo, alienação, grosseria, humor baixo, força física - e de, a partir dessas dualidades, organizar os discursos sobre a cultura letrada, vale verificar qual é o princípio de classificação que constitui a "realidade". Por fim, mas não menos importante, note-se que parte substancial do cânone da literatura brasileira do século XIX foi produzido também por mãos e mentes de pessoas escravizadas nas tipografias espalhadas pelo Brasil ${ }^{10}$. Por enquanto, foi possível levantar evidências que mostram pessoas escravizadas utilizando a escrita e a leitura para, "literalmente", escrever sua liberdade.

\section{REFERÊNCIAS}

ALENCASTRO, Luiz Felipe de. Proletário e escravos. Novos Estudos Cebrap, São Paulo, n. 21, p. 30-56, jul. 1988.

. O trato dos viventes: formação do Brasil no Atântico Sul. São Paulo: Companhia das Letras, 2000.

ARANTES, Adlene Silva. 2005. O papel da Colônia Orfanológica Isabel na educação e na definição dos destinos de meninos negros, brancos e índios na Província de Pernambuco (1874-1889). Dissertação (Mestrado em Educação), Universidade Federal de Pernambuco, Recife, 2005.

BRASIL. Constituição política do Império do Brazil. 1824. Disponível em: <http://www.planalto.gov. br/ccivil_03/constituicao/constituica024.htm>. Acesso em: 17 ago. 2017.

CHARTIER, Roger. A mão do autor e a mente do editor. Tradução de George Schlesinger. São Paulo: Unesp, 2014.

10. Sobre a atividade intelectual presente nas fases de edição e montagem de um livro, ver Roger Chartier (2014), A mão do autor e a mente do editor. 
DANTAS, Raymundo de Souza. Um começo de vida (depoimento biográfico). Rio de Janeiro: Ministério da Educação, 1949.

FREYRE, Gilberto. O escravo nos anúncios de jornais brasileiros do século XIX. São Paulo: Global, 2010. GALVÃO, Ana Maria de Oliveira et al. História da cultura escrita, séculos XIX e XX. Belo Horizonte: Autêntica, 2007.

GODOI, Rodrigo Camargo. Um editor no Império: Francisco de Paula Brito. São Paulo: Edusp, 2016. GUIMARÃES, Pinheiro. História de uma moça rica. Rio de Janeiro: Typ do Diário do Rio de Janeiro, 1861. LUZ, Itacir Marques da. Negros com passos letrados: a ação educativa da Sociedade dos Artistas Mecânicos e Liberais. In: GALVÃO, Ana Maria de Oliveira et al. História da cultura escrita, séculos XIX e XX. Belo Horizonte: Autêntica, 2007. v. 1, p. 9-37.

MACHADO DE ASSIS, Joaquim Maria. Pai contra mãe. In: . Obra completa de Machado de Assis. Rio de Janeiro: Nova Aguilar, 2008a. v. 2.

. Hoje avental, amanhã luva. In: . Obra completa de Machado de Assis. Rio de Janeiro: Nova Aguilar, 2008b. v. 3.

MARTINS, Monica de Sousa. Entre a cruz e o capital: as corporações de ofício no Rio de Janeiro. Rio de Janeiro: Garamond Universitária, s.d.

MARX, Karl. O capital: crítica da economia política. Livro I: o processo de produção do capital. Tradução de Rubens Enderle. São Paulo: Boitempo, 2013.

NASCIMENTO, Abdias. O genocídio do negro brasileiro: processo de um racismo mascarado. São Paulo: Perspectiva, 2016.

RAINVILLE, César de. O Vinhola Brazileiro - novo manual prático do engenheiro, arquiteto, pedreiro, carpinteiro, marceneiro e serralheiro. Rio de Janeiro: Eduardo \& Henrique Laemmert, 188o.

RIBEIRO, Gladys Sabina. A liberdade em construção. Rio de Janeiro: Nova Fronteira, 2002.

ROCHA, Justiniano José da. O Brasil, 10 de dezembro de 1844, p. 1.

RUGIU, Antonio Santonio. Nostalgia do mestre artesão. Campinas: Autores Associados, 1998.

SCHWARCZ, Lilia Moritz. Retrato em preto e branco. São Paulo: Companhia das Letras, 1987.

SILVA, Adriana Maria P. da. Aprender com perfeição e sem coação: uma escola para meninos pretos na corte. Brasília: Plano, 2000.

. "Os meninos das aulas públicas de primeiras letras: Pernambuco, primeira metade do século XIX". In: GALVÃO, Ana Maria de Oliveira et al. História da cultura escrita, séculos XIX e $X X$. Belo Horizonte: Autêntica, 2007. v. 1, p. 271-305.

STOLZE LIMA, Ivana (Org.). História social da língua nacional. Rio de Janeiro: NAU, 2014.

WISSENBACH, Maria Cristina Cortez. Cartas, procurações, escapulários e patuás: os múltiplos significados da escrita entre escravos e forros na sociedade oitocentista. Revista Brasileira de História da Educação, Campinas, n. 4, p. 103-122, jul.-dez. 2002.

\section{SOBRE O AUTOR}

Atilio Bergamini é graduado em Letras (Universidade Federal do Rio Grande do Sul), tem Mestrado e Doutorado em Literatura Brasileira (Universidade 
Federal do Rio Grande do Sul, com estágio sanduíche na Yale Universitiy) e Pós-Doutorado em Teoria da Literatura (Universidade Estadual de Campinas). É professor da Universidade Federal do Ceará. Tem experiência na área de literatura, imprensa, escravidão e educação, com pesquisa nos seguintes temas: imprensa do século XIX, literatura, escravidão.

E-mail: atiliobegamini@gmail.com.

Recebido em 31 de março de 2017 e aprovado em 26 de abril de 2017. 